\title{
Students Further Learning Preferences in Higher Education
}

\author{
Patrik BAŠA, Enikő KORCSMÁROS and Bence CSINGER* \\ J. Selye University, Komarno, Slovakia, patrik.basa111@gmail.com; korcsmarose@ujs.sk; \\ csinger.bence@gmail.com \\ * Corresponding author: csinger.bence@gmail.com
}

\begin{abstract}
In the 21st century, education plays a key role in people's lives. With the help of higher education, we can have a huge number of opportunities and it contributes to the increase of the overall quality of life. Higher education helps to train in the chosen field, to understand the contexts by teaching students analytically and to communicate effectively. The timeliness of our study is primarily due to the fact that education is one of the key factors in the 21st century knowledge-based society. The aim of our research is to examine the preferences of graduating high school students with an excellent and good academic average for further education. In the course of our quantitative research, the opinion of these students came specifically into focus. Our results demonstrate that the factor considered most important by the two groups is different. Our study based on a survey of 270 students in Hungarian institutions.
\end{abstract}

Keywords: decision-making process; preferences; higher education system; enrollment strategy

JEL Classification: I20; I21; I23

\section{Introduction}

Our choice of the topic was basically determined by our interest in a competitive higher education system and our personal experience for the topic was highly motivated. The significance of our study is given by the fact that in today's knowledge-based society, education is one of the most indispensable factor in people's lives. Based on these, our primary goal was to examine that what are the most important motivational factors that play a role in the life of students when they are facing the choice of a higher education institution.

For most people, education is an investment that plays off for both the individual and society. (Riggert, Boyle, Petrosko, Ash, \& Parkins, 2006)

The 21.st century students have a lot of expectations about a higher education institution. Universities need to keep pace with both the expectations and needs of students. (IrvineCode-Richards, 2013)

The motivation for our research is to understand what are the most important influencing factors that influence students today in terms of their intention to continue their studies.

In the first part of our study, with the help of domestic and international literature, we examine the influencing factors that affect students in terms of further learning. This is 
followed by the presentation of the purpose of the research and the methodology we used. As a next step, we provide a comprehensive picture of the validity of the formulated hypotheses and the results of our study. Based on the results the conclusions and recommendations on the topic are formulated. With the help of primary data collection, we conducted a survey among graduating high school students in Hungary.

\subsection{The Decision of Making Process of Students}

It is now internationally recognized that student decisions are influenced by a number of influencing factors and that the main effects of student decision-making processes need to be explored for successful marketing activities of institutions. It is necessary to understand the influencing factors of this process that play a role in the choice of university or college. During the choices, students show the forms of motives for customer behavior. Such motive effects may be different for the social class. In 1995, Kotler and Fox identified five phases in the decision-making process:

- collection of information,

- evaluation of alternatives,

- decision-making process,

- post-decision behavior.

The model helps higher education institutions to understand the mindset of students at different stages of selection. However, the leading factor in the selection of universities and colleges is the close relationship between individual disciplines and career paths. One of the most popular ways to gather information is to visit the institutions 'website, followed by information from current university students. The next step in the decision-making process is to evaluate the alternatives, which includes gathering information about university alternatives and narrowing them down. Students then choose an alternative from their choice set. In the assessment phase, students objectively justify their decision, i.e., compare the characteristics of each institution. In the lives of students, there are some people who extremely influence their selection process. The number one person includes parents, friends, and school teachers, while the group of persons number two includes persons such as university lecturers. In 2013, Haynes et al found that parents have significant influence over their children. (Nemar \& Vrontis, 2016)

The primary task of students entering higher education is to prepare for their future profession. Apart from this, the ability to solve problems, work in a team, communicate properly are essential to making professional decisions today. (Chernikova, Heitzmann, Stadler, Holzberger, Seidel, \&Fischer, 2020)

\subsection{Motivational Factors for Students in Choosing a Higher Education Institution}

Choosing the right university is increasingly becoming a kind of critical investment choice. Institutions are more attractive if they are able to communicate their value perceptions through interactions with prospective students. Regarding the selection process, we can talk about certain preferences, which can be personal preferences, parental preferences, 
admission scores, university rankings, counselors and friends. One of the most influential factors is, of course, personal preference, as students rely heavily on their own ideas and desires. According to Soutar and Turner (2002), students attach important importance to the general preference criteria, which are:

- the type of courses available,

- the university environment,

- the quality of faculty education,

- type of university,

- the academic reputation of the university.

In addition, it is important to mention personal preferences, the location of the institution, the family's perception of the university, and which university / college the student's friends will go to. In determining the most important factors, students rank the level of importance of each preference. (Nemar \& Vrontis, 2016)

One of the most important factors among students' pre-qualification experience is the choice of higher education institution. Students whose values and beliefs fit the chosen institution will be satisfied with the choice, which will contribute to obtain a higher education degree. Selection involves matching students 'individual characteristics and values to the institution. Selection itself can be defined as a three-step process that includes the following elements: predisposition, search and choice, which contribute to the student's behavior and attitude towards the higher education institution. The influencing factors of all three stages include the economic and social situation. (Nora, 2004)

In their 1981 research, Hooley and Linch identified six variables that students take into account when selecting an institution. The six factors are the location of the university, the distance from home, the suitability of the courses, the reputation of the university, the type of university, and the advice of parents and high school teachers. (Hooley-Linch, 1981)

In a 2002 study, Soutar and Turner (2002) concluded that the factors most influencing the student selection process are suitability of the course, reputation, job opportunities, and the quality of teaching.

In their 2008 study, Jusof, Ahmad, Tajudin, and Ravindran (2008) found that prospective university / college students and their parents found financial assistance to students to be one of the most important influencing factors. Their research concluded that the availability of the required program also plays a key role in the selection process. In support of this finding, in 2009, Wagner and Fard noted that the cost, value, and quality of a degree in education are the three most important factors influencing student choice.

The choice of higher education institution is a group decision that determines the future of the student, within which the family has an extremely important role to play. It is important to emphasize that, over time, student decision-making is much more the responsibility of the individual, but the influential role of the family remains. In his doctoral dissertation Rámháp (2017) states that the students in Hungary can be classified taking into the account their further learning attitude into the following groups: prestige-oriented, experience seekers and considered. For the first group it is important to acquire outstanding 
knowledge, ha serious career plans and an important role is played by the standard of instructors and good university reputation. For the second group in contrast the good community and atmosphere is the most important factor. For the, meeting the minimum conditions is the main goal. For students in the third group, the primary considerations are comfort, affordability and favorable future job opportunities. Today, this information can play a key role in shaping the marketing and communication strategy of universities.

The basic of a well-developed marketing strategy is to keep the target group informed. In her doctoral dissertation in 2007, Kuráth (2007) distinguishes between external and internal influencing factors. External influencing factors include the demographic environment, the accessibility of different university buildings, their unique nature and the different funding methods. Groups of internal influencing factors include admission requirements, marketing activities, quality of education, training scale, university equipment, career opportunities and research opportunities. Cultural opportunities offered by the institutions can also be influencing factors. Enrollment marketing activities can play an important influential role in students decision-making processes.

In 2011, Császár and Németh (2011) distinguished five different roles in terms of further learning decision-making. The initiator is the student who would like to continue her/his studies. In the case of parents, we can talk about a person whose goal is for their child to continue their studies. The influencing category is extremely broad. These include parents, friends, acquaintances, society and the workplace. There is often a situation where parents consider individual goals, but in terms of funding, they make the final decision. Thus, the financial situation of the family also plays an essential role in the selection. At the stage of the decision-making process, when the settlement choice and housing are the focus, mutual decisions are often made. It is important that the parents provide their children with good advice and experience when they make a decision.

As a final step, it is important to mention that the final decision is often related to the obvious and hidden costs of higher education. Especially nowadays, it is an extremely important influencing factor for students whether an institution offers some kind of financial incentive support. Canché's (2018) study also shows that students do not ignore institution characteristics either, the local accessibility of a higher education institution has a positive effect on the willingness of local students to continue their studies.

\section{Methodology}

The main goal of our research is to expand the published literature on the topic by providing an insight into the motivational factors which have an influential effect when students are faced with the choice of a higher education institution. In our study we would like to point out the student decision-making process and the most significant influencing factors. For the rest of our work, our goal is to provide a comprehensive picture of the topic in Hungary, which can help to expand the literature on the subject. To perform our research, we performed primary data collection, which took the form of quantitative survey. Our questionnaire was created using Survio and Google Form Builder software. During our contact with the secondary schools, we asked the teachers of each institution to fill in the 
questionnaire only with their graduate students, which was sent to them in the form of direct mail. We thought that we could provide an authentic and comprehensive picture of the influencing factors that arise in Hungarian students only if we specifically addressed them. The first step was to encode the feedback data using Microsoft Excel. Subsequently, we examined the correctness of our hypotheses with the help of SPSS program. Our questionnaire contained 8 questions. The structure of the question groups is shown in Table 1.

Table 1. Structure of question groups

\begin{tabular}{|l|l|l|l|l|}
\hline Question group 1. & Question group 2. & Question group 3. & Question group 4. & Question group 5. \\
\hline $\begin{array}{l}\text { Classification } \\
\text { based on study } \\
\text { results }\end{array}$ & $\begin{array}{l}\text { Intention to } \\
\text { continue learning }\end{array}$ & $\begin{array}{l}\text { Influencing factors } \\
\text { in the selection of a } \\
\text { higher education } \\
\text { institution }\end{array}$ & $\begin{array}{l}\text { Preference for domestic } \\
\text { or foreign institutions, } \\
\text { justification, factors } \\
\text { influencing change in } \\
\text { decision }\end{array}$ & Demographic data \\
& & & \\
\hline
\end{tabular}

A total of 311 high school graduates joined our data collection. The number of completed and evaluable responses was 270 that could be used in the analysis. In examining our hypotheses, we used descriptive statistical methods, including cross-tabulation analysis. A significance level of $5 \%$ was determined during the evaluation. Chi-square test was used to analyze the variables.

\section{Results}

Following the theoretical review of the study, we present the results of our research. With the hypotheses related to the topic, our goal was to examine the influencing factors affecting Hungarian students when they choose a higher education institution. Following a review of the literature, the following research question was formulated in us:

RQ: What are the main factors that are the most important motivating factors for choosing a university for Hungarian students with an excellent and good academic average?

The following hypotheses have been formulated on the topic:

Assumption 1: Students who belong to the group of students with an excellent academic average are the most important factor in choosing a higher education institution is the standard of the university.

Assumption 2: For students with an excellent academic average, the reputation of the higher education institution is more important to then for students with a good academic average.

In the first round, we were curious to see if there was a difference between students with good (4) and excellent (5) averages for the factors considered most important. The distribution of responses is summarized in Figure 1. It is clear that the two lines follow an almost identical curve. There are some differences between two variables, which are the standard of the university and the reputation of the university, which excellent students rated as a more important factor when choosing a higher education institution. We hypothesize that because excellent students are the best, they require that the best decision be made when selecting higher education institutions. 


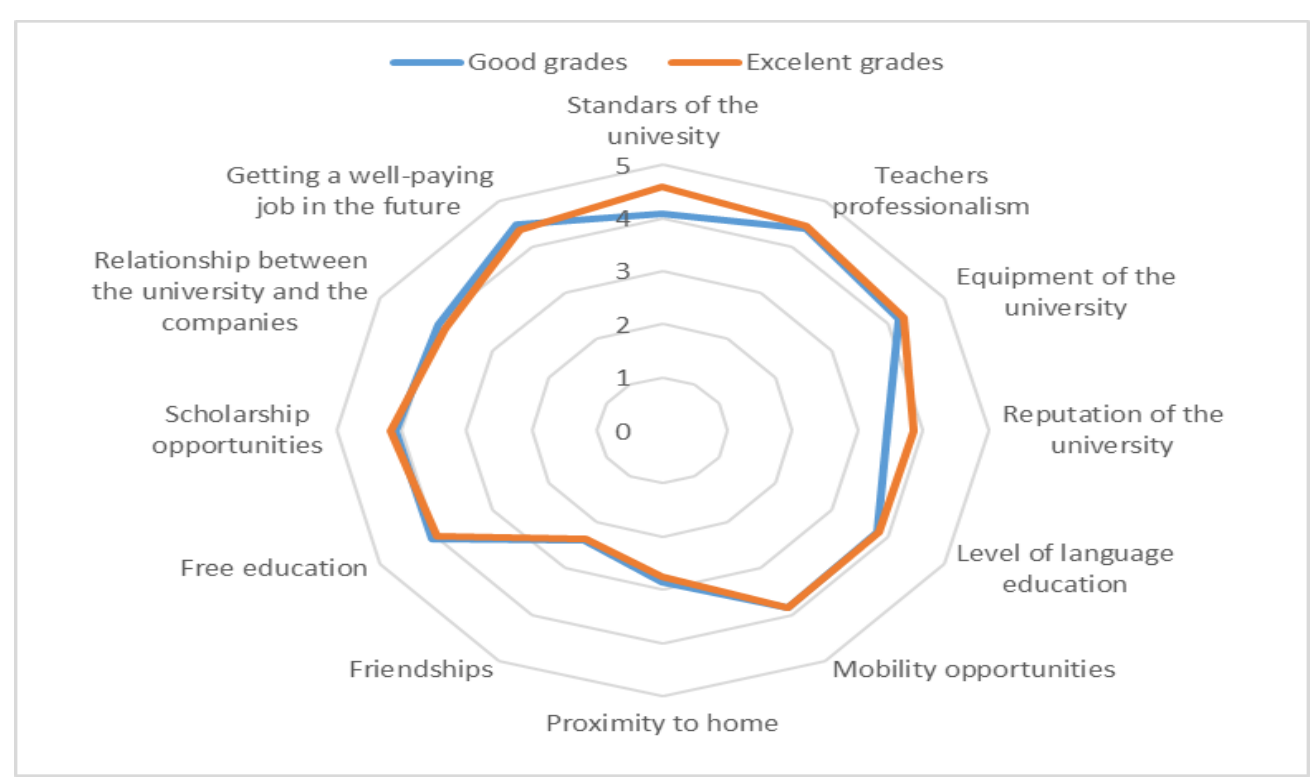

Figure 1. Responses from students with excellent and good grades about the importance of each factors

Based on the figure, it can be concluded that the first assumption is true. The figure clearly shows that for students with an excellent academic average, the most important motivating factor is the standard of the university. Our second assumption was also confirmed, as it is clear that the university standard is a more important factors for students with the best academic average. The figure also helps to encourage Hungarian students to continue their studies in Hungarian higher education institutions.

\section{Discussion}

The first part of our research, we examined the individual steps of the student decisionmaking process in the 21st century with the help of domestic and foreign literature. The significance of the model is that it helps universities and colleges to understand a student's way of thinking, which plays a key role in shaping the enrollment strategy. After that we provided in insight into the preferences that arise during the selection process. Based on the literature review, one of the most important factors in the selection process is the personal preference for students. As a next step we put great emphasis on the three steps of the decision-making process and reviewed how and to what extent the significance of each influencing factor has changed over the years. Following the literature review, the aim and the methodology of the research were presented, followed by the results of the work. In this chapter, a research question and two assumption related to the topic were formulated, in which we focused exclusively on the students who performed well and best. In the last part of the study, we summarized the results of the work and formulated conclusions and suggestions.

\section{Conclusions}

The main aim of our research was to examine those Hungarian high school graduates who have a good or excellent study average. Based on this our research question was formulated, on the basis of which it can be established that for students with the best 
academic average, the most important motivating factor is the standard of the university, which is followed by the professionalism of the lecturers. In contrast, for students with a good academic average, the most important is to get a well-paying job in the future. The professionalism of the lecturers in in the second place in their case as well. The results can serve as a good starting point for universities and colleges in creating an enrollment strategy. That is why we set a goal for the future, after the end of the health crisis situation, to expand our database as a first step in relation to Hungary, in order to get an even more comprehensive picture of the topic. In the distant future our aim is to expand the research to an international level.

Acknowledgments: The scientific article is a partial output from the KEGA project 005UJS-4/2019 entitled "Streamlining Managerial Sills of the generations $\mathrm{Z}$ and $\mathrm{Y}$ by gamification on the context of linking science and practice", which is solved at the Faculty of Economics and Informatics of the J. Selye University in Komárno.

\section{References}

Canché, G. S. M. (2018). Nearby collage enrollment and geographical skills mismatch: (Re)conceptualizing student out-migration in the American Higher Education System. The Journal of Higher Education, 89(6), 892-934. https://doi.org/10.1080/00221546.2018.1442637

Chernikova, O., Heitzmann, N., Stadler, M., Holzberger, D., Seidel, T., \& Fischer, F. (2020). Simulation-based learning in higher education: A meta analysis. Review of Educational Research, 20(10), 499-541. https://doi.org/10.3102/0034654320933544

Császár, M. Z., \& Németh, J. (2011). Some aspects of human capital production in Hungarian higher education. Central European Regional Policy and Human Geography, 1(1), 27-35.

Hooley, G. J., \& Lynch, J. E. (1981). Modeling the student university choice process through the use of conjoint measurement techniques. European Research, 9(4), 158-170.

Irvine, V., Code, J., \& Richards, L. (2013). Realigning higher education for the 21st-century learner through multi-access learning. MERLOT Journal of Online Learning and Teaching, 9(2), 172-186.

Kuráth, G. (2007). A beiskolázási marketing szerepe a hazai felsőoktatási intézmények vonzerőfejlesztésében. (The role of enrollment marketing in the attraction development of Hungarian higher education institutions. Doctoral dissertation) Pécsi Tudományegyetem Közgazdaságtudományi Kar. Regionális Politika és Gazdaságtan Doktori Iskola. Doktori értekezés.

Nora, A. (2004). The role of habitus and cultural capital in choosing a collage, transitioning from high school to higher education, and persisting in college among minority and nonminority students. Journal of Hispanic Higher Education, 3(2), 180-208. https://doi.org/10.1177/1538192704263189

Rámháp, S. (2017). Felsőoktatási továbbtanulási motivációk Magyarországon. A változó ifjúság és a piacosodó felsőoktatás tükrében. Doktori értekezés tervezet. (Motivations for further education in higher education in Hungary. In the light of changing youth and marketable higher education. Doctoral dissertation draft.) Széchenyi István Egyetem. Regionális- és Gazdaságtudományi Doktori Iskola

Riggert, C. S., Boyle, M., Petrosko, M. J., Ash, D., \& Parkins, R. C. (2006). Student employment and higher education: empiricism and contraction. Review of Educational Research, 76(1), 63-92. https://doi.org/10.3102/00346543076001063

Soutar, G. N., \& Turner, J. P. (2002). Students' preferences for university: A conjoint analysis. The International Journal of Educational Management, 16(1), 40-45. https://doi.org/10.1108/09513540210415523

Yusof, B. M., Ahmad, B. B. N. S., Tajudin, M. B. M., \& Ravindran, R. (2008). A study of factors influencing the selection of a higher education institution. Unitar e-Journal. 4(2), 27-40. 